\title{
Psychic distance and cross - border cooperation of SMEs: An empirical study on Saxon and Czech entrepreneurs' interest in cooperazion ${ }^{*}$
}

\author{
Cornelia Zanger, Radka Hodicová, Hansjoerg Gaus**
}

This paper examines the relationship between the psychic distance of decision makers in SMEs from specific foreign markets and their interest in cooperation with companies from those countries. Based on a review of the literature and a qualitative empirical study among entrepreneurs in the Saxon-Czech border area, the paper identifies the central explanatory variables of psychic distance, thus contributing to a theoretically-based conceptualization of this construct. Previous conceptualizations of psychic distance are extended and specified. This reveals the necessity for a wider inclusion of perceived differences in the political and legal situations, the mind-set as well as the historical development.

Der vorliegende Beitrag untersucht den Zusammenhang zwischen der psychischen Distanz mittelständischer Unternehmer gegenüber konkreten Auslandsmärkten und ihrer Bereitschaft zur Kooperation mit Unternehmen aus diesen Ländern. Auf Basis des Literaturstandes sowie einer qualitativen empirischen Untersuchung bei Unternehmern im sächsisch-tschechischen Grenzraum werden zentrale Erklärungsvariablen dieses Konstruktes identifiziert, wodurch ein Beitrag zu einer theoretisch fundierten Konzeptualisierung der psychischen Distanz geleistet wird. Die in der Literatur vorzufindenden Konzeptualisierungen der psychischen Distanz werden erweitert und präzisiert. Dabei wird die Notwendigkeit einer stärkeren Einbeziehung von wahrgenommenen Unterschieden in politisch-rechtlichen Bedingungen, Mentalität sowie historischer Entwicklung deutlich.

Key words: psychic distance; cross - border cooperation; internationalization; SMEs

* Manuscript received: 15.05.07, accepted: 11.02.08 (1 revision)

** Cornelia Zanger, Prof., Chemnitz Unniversity of Technology, Germany. Main research areas: Marketing communication, experiential marketing and entrepreneurial marketing. Corresponding address: zanger@wirtschaft.tu-chemnitz.de.

Radka Hodicová, Dr., Iventa Czech Management Consulting, Czech Republic. Main research areas: International and intercultural marketing and corss - border cooperation of SMEs.

Hansjoerg Gaus, Dr., Chemnitz University of Technology, Germany. Main research areas: Consumer behaviour, marketing communication and entrepreneurial marketing. Corresponding address: hansjoerg.gaus@wirtschaft.tu-chemnitz.de. 


\section{Introduction}

Being involved in cross-border corporate activities has been increasingly typical for small and medium-sized companies since the 1980s (Larimo 2003; Lamb/Liesch 2003). As the expenditure is manageable, cooperation is particularly recommended as a suitable internationalization strategy for small and medium-sized companies, which normally possess only limited resources (Haussmann 1997; Müschen 1998). Possible benefits include the facilitation or acceleration of the opening-up of markets, cost savings and a better access to know-how (Bühner 1991). Small and medium-sized companies often choose their potential cooperation partner in the neighbouring country because of their geographical proximity and regional bonds. This results in active cooperation particularly in regions close to a border.

The relevant literature on the internationalization of small and medium-sized companies comprises a large number of works which focus on the selection of a suitable cooperation partner (Bleicher 1992; Börsig/Baumgarten 1997; Binder/Lux 1997). Functional reasons and strategic limits aside, the preselection of suitable cooperation partners includes in particular the specific attitudes of the management as an important part. This disposition is based on empathy with, or aversion to, certain countries, e.g. as a result of negative experience (Köhler/Hüttemann 1989; Berndt/Altobelli/Sander 2005). There is subjective influence on the decision-making process particularly for small and medium-sized companies with the entrepreneur's personality playing a central role (Dichtl et al. 1983; McGaughey et al. 1997). According to his or her limited rationality (March/Simon 1976), the extension of the corporate activity across borders takes place with preference to some markets while neglecting other objectively comparable countries (Kornmeier 2002).

Works on psychic distance discuss the importance of the entrepreneur's personal attitudes towards a foreign market in the course of reaching a decision on internationalization. This construct can contribute to the explanation of the individual's socio-cultural preference for certain markets and is the object of an extensive scientific discussion. Numerous authors refer to this construct and attempt to demonstrate its relevance particularly to the export behaviour of companies (Stöttinger/Schlegelmilch 1998; Fletcher/Bohn 1998; Sousa/Bradley 2005). To a certain extent in this process they reach very inconsistent conclusions with regard to the interrelation between psychic distance and internationalization. These inconsistencies result in some authors' challenging the explanatory relevance of the whole concept or at least explaining it as having declining importance in this construct in the time of globalization (Child/Ng/Wong 2002; Axinn/Matthyssens 2001).

In this paper, however, it is assumed that the reason for these ambiguous findings is largely due to a lack of terminological specification and consequent shortcomings in conceptualization and operationalization. Following the up-to- 
date description of relevant literature in this field of research and an explorative empirical study, this work is to contribute to a suitable conceptualization of psychic distance by identifying the central explanatory variables of this construct. The examination is carried out against the particular background of the cooperative behaviour of companies from the Saxon-Czech border area. Qualitative in-depth interviews with entrepreneurs from that area are used to identify the aspects responsible for the differences in their interest in crossborder cooperation. The respondents were asked about cooperation with foreign companies in general as well as with those from their respective neighbouring region (Saxony or the Czech Republic), thus allowing a comparison between general and regional international cooperation.

The integration of the literature analysis and the empirical results permits a precise and comprehensive identification of explanatory variables of psychic distance as well as their effects on the interest in cooperation. Apart from consolidating the state of research on cooperation as an internationalization strategy for small and medium-sized companies, this work also adds to the neglected issue of cooperative behaviour between small and medium-sized companies in border areas with the main emphasis on the new external borders of the European Union. In practice, the results can be used to draw conclusions about the promotion of interest in cooperation. Finally, this study is to be discussed critically in order to obtain implications for further research.

\section{Theoretical frame of reference for the entrepreneur's interest in cross-border cooperation}

The entrepreneur's interest in internationalization describes the individual's motivation to get involved in foreign activities, which shows his or her intention to adopt internationalization behaviour. Consequently, it is not a matter of actual behaviour but merely a corresponding behavioural intention. The interdependencies between these two concepts are concisely clarified by Ajzen's (1988) Theory of Planned Behaviour, which corresponds to the comprehension of limited rationality of entrepreneurial decisions opined here (Bamberg/Schmidt 2000; Simon 1997; Cyert/March 1963). According to the Theory of Planned Behaviour, the actual behaviour is explained by the behavioural intention which, in turn, is formed by the attitude towards the behaviour, the subjective norm (the perceived behavioural norms of the social environment and the motivation for their consideration) as well as the perceived behavioural control (the perceived individual control over the behaviour to be performed) (Ajzen, 1988). The individual interest in internationalization and the actual internationalization behaviour only partly match since there are a number of situational factors which have to be taken into account that, in spite of high interest, may exclude the performance of a type of behaviour (e.g., limited resources) (Schäper, 1997). 
Since this article focuses on cooperation strategies, it is furthermore imperative to augment the term 'interest in internationalization' with aspects of cooperation. Schäper (1997) describes 'interest in cooperation' as the existing motivation of companies' decision makers to consider and, if applicable, to put into effect cooperation as an alternative action to solve operational problems independent of a specific cooperation project. This reveals a certain reactive comprehension since the interest in cooperation is merely viewed as a reaction to operational problems. The individual interest in cooperation can, however, also involve active elements, e.g., in form of the motivation to choose cooperation for company growth purposes. According to Endress (1991), the interest in cooperating comprises the partners' different motive clusters and motives as well as a number of inherent necessities and the general inclination of the companies to find problem solutions together, and to achieve improvements in the situation through cooperation.

From an international perspective, the interest in cross-border cooperation is understood here as being the individual motivation to enter into cooperation with one or more foreign enterprises. Starting from the question formulated by this article, it is not the intention of this examination to include the interest in cross-border cooperation in general but rather the interest in cooperation with companies from a specific country.

Apart from this interest, the literature also mentions other concepts that contribute to the explanation of the entrepreneur's motivation to start activities abroad. However, an imprecise usage of terms like 'tendency to export', 'motivation to get involved abroad' or 'willingness to start exporting' leads to the concept of interest in cooperation often being equated with the concept of cross-border business orientation which is also frequently discussed in relevant literature.

Dichtl and Müller (1992) describe 'cross-border business orientation' as a whole cluster of individual characteristics and views which represent relevant predispositions for the cognitive and behavioural analysis of the international environment. However, the construct of cross-border business orientation fails to replace the interest in cross-border cooperation as understood by this article, since unlike the interest in cross-border cooperation, cross-border business orientation refers to the personal predispositions for foreign involvement in general, thus merely representing a precondition for the entrepreneur's interest to cooperate with enterprises from a specific country. Apart from the crossborder business orientation, the entrepreneur's general interest to start crossborder cooperation is also influenced by his or her attitude towards cooperation as a corporate strategy (see Figure 1).

The entrepreneur's strong cross-border business orientation and his or her favourable attitude towards cooperation as a corporate strategy constitute necessary, but not sufficient, conditions for interest to be shown in entering into 
cooperation with an enterprise from a certain country. If these conditions are fulfilled, it can be assumed that the entrepreneur is in principle open to cooperation with a foreign company. However, the entrepreneur's interest in cooperation diverges depending on the country of origin of the potential cooperation partner. At this point, psychic distance comes into play, since the differentiation between the general and specific level of interest in cooperation makes it necessary to consider the subjectively perceived familiarity or foreignness towards certain foreign markets.

Figure 1. Theoretical frame of reference for the entrepreneur's interest in crossborder cooperation:

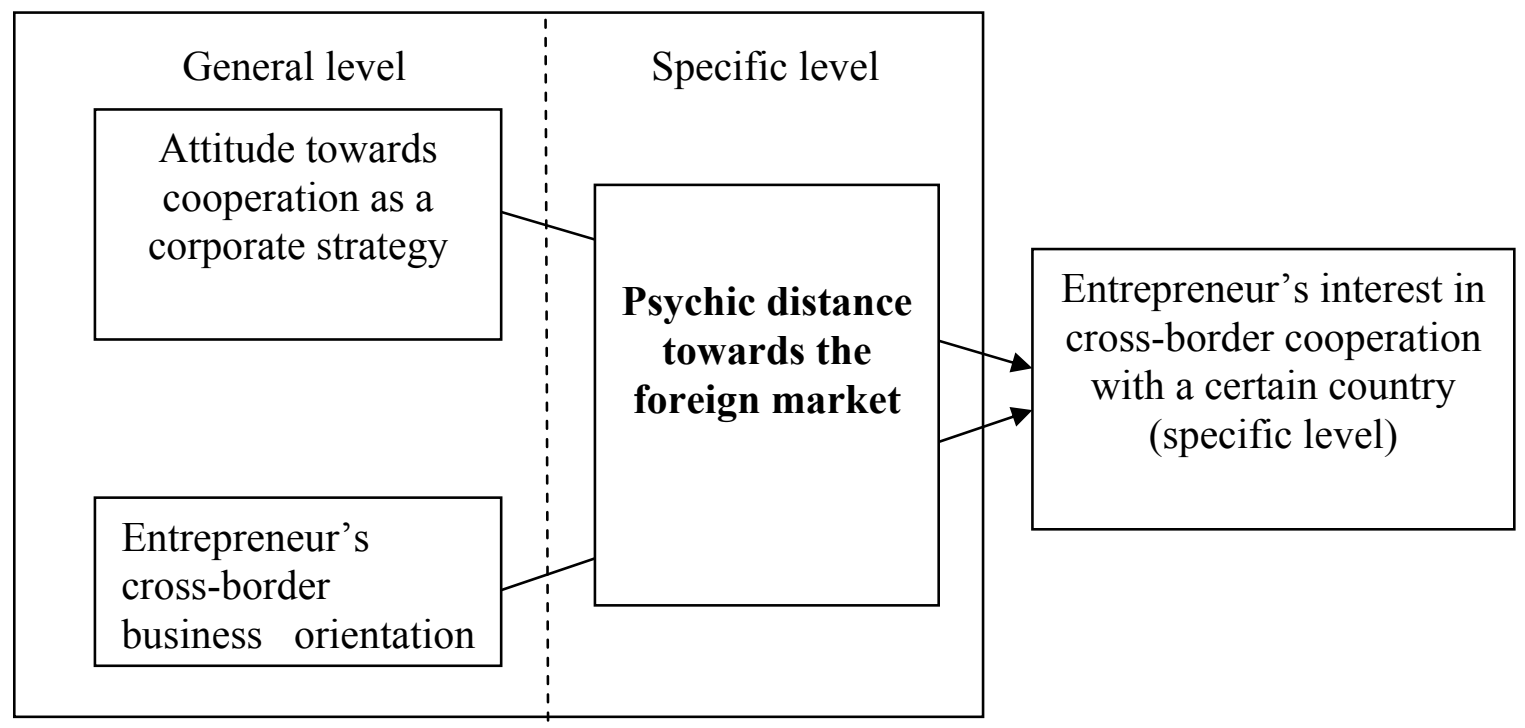

\section{Conceptualization of the construct of psychic distance}

The roots of research on psychic distance are linked with the name Beckermann (1956) who employed this term for the first time in the context of distribution in international trade, but without supplying a defining terminology. Only towards the end of his study does he mention the word 'psychic' (in quotation marks) in order to emphasize a possible influence of factors other than geographical distance. Apart from personal contacts, he also brought up language as a determinant that may influence the decisions of companies.

During the last 30 years the understanding of the term psychic distance has shifted from a merely objectively perceptible to a far more subjectively determined construct. Already in the 1970s the authors of the Uppsala School spoke about the perception of other countries (Wiedersheim-Paul/Olson/Welch 1978:48) which, however, was determined through objective differences between the home market and a foreign market (Nordström/Vahlne 1994). The inclusion of individual perception as an important component of the construct of 
psychic distance is attributed to the Mannheim research group around Dichtl. In their works they considered psychic distance as perceived foreignness towards a foreign market from a purely individual perspective (Dichtl et al. 1983; Müller/Köglmayr 1986). Dichtl et al. (1983:440) defined psychic distance as the extent to which foreign markets are experienced as unfamiliar.

Despite the fact that the need to include individual perception is similarly emphasized in most recent research, numerous authors continue to determine psychic distance merely through objective differences between countries (Zhu/Yang 2004; Holtbrügge 2005). This can be explained by an insufficient demarcation of the construct of psychic distance from other distance concepts, particularly from cultural distance.

Unlike other distance concepts, the concept of psychic distance has to be related to the individual (Sousa/Bradley 2006). Whereas, for example, cultural or economic distance can be determined at country level (Hofstede's 1993) cultural dimensions or comparing the gross domestic products), the reference level of psychic distance is restricted to the individual's perception. As illustrated in Figure 2, this paper argues that the other, objectively determinable and reciprocal constructs may constitute a basis for the development of psychic distance, but when they are considered separately, they only have limited ability to explain these feelings of foreignness. In contrast, it is particularly important how the individual, due to personal experience, knowledge and characteristics, perceives and processes the objective distances.

Figure 2. Demarcation of psychic distance from other distance concepts:

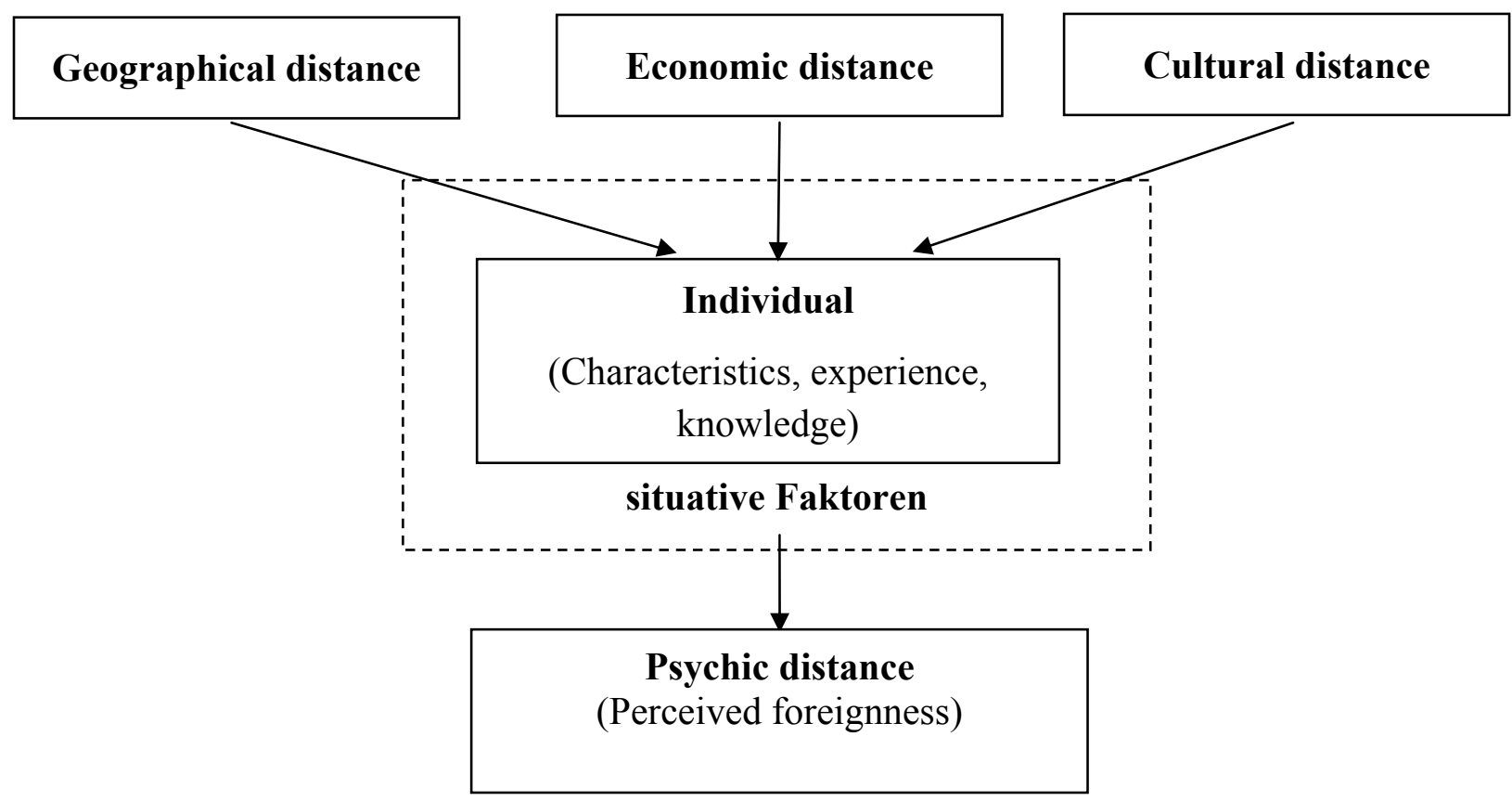


The demarcation of the term psychic distance requires the inclusion of not only individually perceived differences between countries but also perceived consequences of these differences with regard to a specific way of examining the particular foreign market. Accordingly, this paper defines psychic distance as individually perceived foreignness of a country resulting from the subjective interpretation of the perceived differences between the home and a foreign market.

Such an understanding is based on findings from the field of foreignness research, which emphasizes the importance of a comparison between the 'own' with the 'strange' for the development of psychic distance (Thomas 1991). However, on the whole, the entrepreneur finds it difficult to evaluate a foreign market on the basis of merely actual (objective) characteristics. This is due to a lack of information about the foreign country that the entrepreneur faces in comparison with his or her home country. Not only the process of information acquisition but also the subsequent information processing are marked by a subjective rationality (Pfohl/Braun 1981). As a result, a foreign market is evaluated using not only objective characteristics, but similarly stereotypes and prejudices connected with the corresponding country which can replace the lacking information about the country (Müller/Kornmeier 2002).

However, the home market is evaluated with recourse to subjective characteristics, too. As a result, the markets are compared on the basis of merely subjective images of both markets (country images). This comparison is followed by the identification of the most important perceived differences between both countries, which provide a basis for the interpretation of the consequences of a possible examination of this country.

During the interpretation phase, the entrepreneur has to ask which consequences these differences may have for his or her cooperation with a company from the particular country. These consequences are evaluated, which results in a feeling of foreignness or familiarity that can be considered as a personality-related factor of an internationalization decision. It is assumed that the feeling of foreignness/familiarity towards a foreign market exerts an influence on whether the entrepreneur is motivated to have a closer look at that country. With a predominant feeling of familiarity, the entrepreneur is more likely to be willing to start activities abroad than in the case of prevailing feelings of foreignness (Holzmüller/Kasper 1990; Müller 1991; Stöttinger/Schlegelmilch 2000).

The subjective processing of perceived differences originates from the subjective reconstruction of reality (Hiebsch 1986). In the course of its perception and evaluation, an object (a country) is given certain characteristics. Due to limited information processing capacity, individuals confine themselves to a relatively small number of categories, which are assigned to the evaluation object. The categorization frequently involves a systematic distortion of an object evaluation. The foreign markets are accordingly often perceived on the 
basis of categories formed by the entrepreneur as a result of knowledge and experience and activated at the time of evaluation. During that process, a number of characteristics are frequently emphasized whereas others are suppressed as not relevant.

Figure 3. Theoretical conceptualization of the construct of psychic distance:

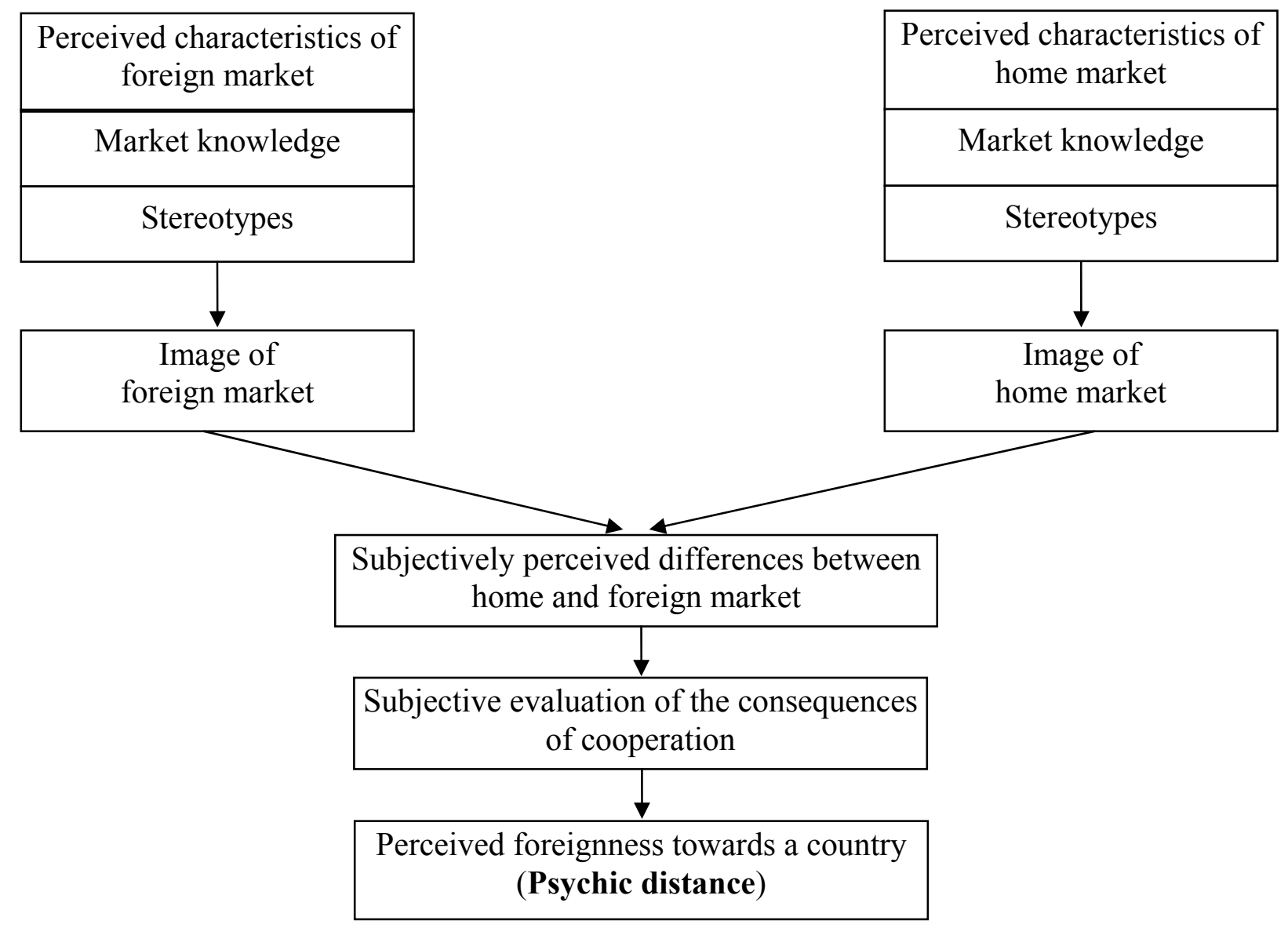

To decide which differences between the foreign and home market are perceived at all by the entrepreneur depends on different factors. They include on the one hand personal characteristics and on the other hand the characteristics of the situation in which the decision is made. Furthermore, cultural specifications for the selection and interpretation of the perceived differences have to be considered (Bradley 1991). As a result, psychic distance must be regarded as a construct at the individual level. However, individuals belonging to the same culture tend to take equal characteristics into account while evaluating the different ones.

Having described the conceptual framework of this paper in the sections on interest in cross-border cooperation and the role of psychic distance, the following chapter will elaborate on the situational background, the method and the most important results of the empirical study. 


\section{Background, method and results of the empirical Study}

\subsection{Situational background of the Cooperation between Companies in the Saxon-Czech border area}

Until the fall of the 'Iron Curtain' both parts of the Saxon-Czech border area developed similarly (centralization of political power, centrally planned economy, etc.) but separately from each other since cross-border activities were not usual at regional level. Despite the EU's external border having run between Germany and the Czech Republic until April 2004, there are a number of similarities between the Saxon and the Czech part of the border area, which particularly result from the structural change at the beginning of the 1990s. The dismantling of traditional sectors (mining, heavy and textile industries) led to above average unemployment and a consequent movement of the population. However, the region's peripheral location offers a range of potential for cooperation (Brezinski/Leick 2004). The region's status as one of the EU's most important development areas is another reason for the rapid development in mutual cooperation between local authorities, schools, universities and, not least, companies from Saxony and the Czech Republic, too. According to Zich (1999) the number of contacts between Germany and the Czech Republic is constantly increasing. However, only a certain proportion are of permanent duration.

A closer examination of relations between companies in the Saxon-Czech border area reveals that they are often based on export/import activities or cooperation without contribution of capital (Brezinski/Leick 2004). Thus, supply contracts and contract processing constitute the most common forms of cooperation. With regard to areas of cooperation, there is a clear preponderance of cooperation in production, purchasing and distribution (Brezinski/Leick 2004). This indicates that the motives for cross-border activities of companies mainly consist in the cost gap between both countries.

A different stage of development in the two parts of the border area, the existing language barrier, different mind-sets of the people, both countries' problematic relations in the past as well as the existence of many stereotypes and prejudices result in the fact that, in spite of geographical proximity and many similarities, cooperation between Saxon and Czech companies does not always run smoothly (Castell 2001; Schroll-Machl 2000). However, in order to maintain the SaxonCzech border area's status as a stable region for the resident small and mediumsized companies, it is imperative to build up more intensive cooperative relationships (e.g., in research and development) which have the potential to last into the future. 


\subsection{Method}

This article aims to contribute to theory formation in the research area of psychic distance. With reference to this goal, the selection of a qualitative approach appears to be particularly suitable. The qualitative approach of the analysis, emphasized as essential in the relevant literature (Stöttinger/Schlegelmilch 2000), permits a profound examination of this so far insufficiently researched area.

Between April and June 2005 a total of 18 qualitative single interviews were conducted asking Saxon and Czech entrepreneurs from small and medium-sized companies about their motivation to cooperate with foreign enterprises. For the purpose of this survey, a guideline was developed, which concentrated on both the motivation to generally cooperate across borders and the cooperation in the Saxon-Czech borderland. Entrepreneurs from different industrial sectors were chosen deliberately to obtain a preferably large spectrum of information.

The selection criteria were as follows:

- SMEs (max. 250 employees)

- Located in the Saxon-Czech border area.

- Led by one manager or owner (i.e., only one decision maker with regard to internationalization).

- Industries typical for the region (e.g., engineering, textile manufacturing) but also a mix of industries including service providers in order to have a diverse sample.

- Entrepreneurs with, as well as without, experience in international cooperation (on the general level/ in the Saxon-Czech border area).

- Entrepreneurs with positive as well as negative experience and different intensity of cooperation.

These criteria were already addressed during the first telephone contact (particularly the experience in cooperation and the extent of that experience) and accordingly it was decided whether the individual entrepreneur was interviewed personally.

The structure of the resulting sample reflects the regional industrial structure. Since the Saxon-Czech border area is mainly characterized by the engineering industry, mechanical engineering companies also made up the largest number of those asked. The sample also included service providers, wood fabricators, companies from the textile industry and other sectors. Table 1 shows the demographic characteristics of the respondents and the characteristics of the companies.

Due to the orientation of the empirical study towards small and medium-sized companies. The majority of those asked reported cooperation particularly with neighbouring countries or with other European countries. The Czech interviewees mainly cooperate with German companies whereas the survey does 
not show a clear distribution of countries amongst the respondents from Saxony. While some Saxon entrepreneurs prefer exclusively domestic cooperation partners, the sample also includes individual entrepreneurs who cooperate with distant countries (e.g., the USA, Arab countries). The cooperation intensity of the entrepreneurs interviewed differs as well depending on their education, age and knowledge of foreign languages. A higher intensity of cross-border cooperation is noticeable amongst entrepreneurs with a university degree who are older than 50. As to knowledge of foreign languages, entrepreneurs without, or with only limited skills in a foreign language have only little cooperation with foreign companies. The reason for the Czech interviewees' concentration on Germany is linked to this country's high market potential and their German language skills. Seven out of nine entrepreneurs interviewed in the Czech Republic said they had a reasonably sound knowledge of German.

Table 1. Characteristics of respondents and their companies $(n=18)$ :

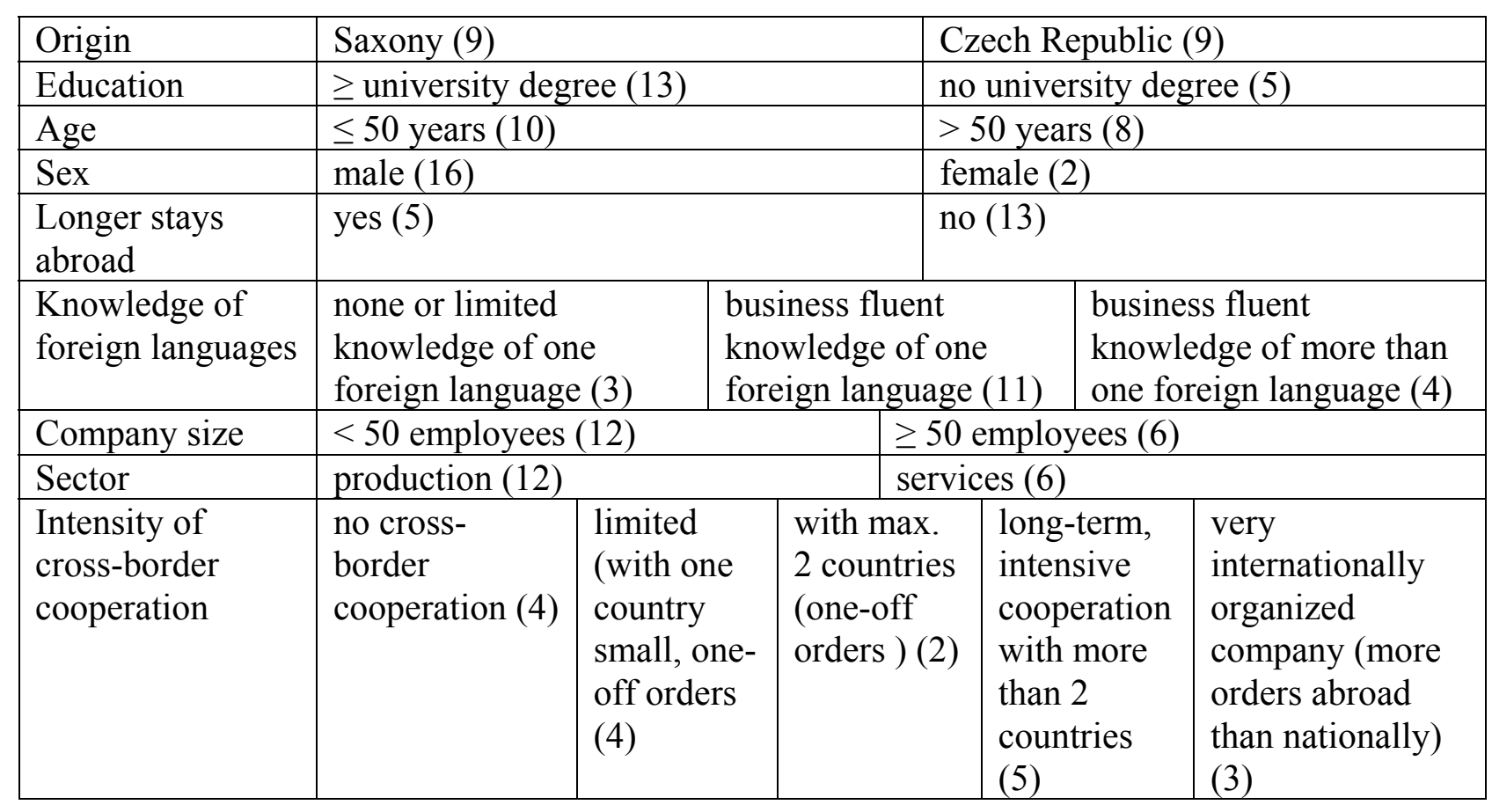

The interpretation of the interviews was carried out using the principle of structured summarization (Roll 2003), which is based on the approach of qualitative content analysis by Mayring (1997). The principle of structured summarization combines the advantages of both the method of summarization and structuring suggested by Mayring. The method can particularly be exploited for a holistic view on each case under examination as well as the consideration of its peculiarities. Furthermore, the interpretation employs the transcribed text and the theory-based findings at the same time. Whereas the main categories are equal for all cases under examination since they are developed on the basis of 
theoretical principles, the subcategories are case-specific because they derive from the transcribed text itself (Roll 2003).

The analysis of qualitative interviews involves a natural loss of information which comes about because of the paraphrasing as well as the generalization of statements. As a result, the researcher has to make every effort to keep crosschecking with the original text in order to keep this loss of information as low as possible (Mayring 2002). Therefore, the analysis was not just performed by the researcher herself, but also simultaneously by a second person. This person was tasked to reveal discrepancies that may have resulted from the researcher's subjective influence (so-called concurrent validation; Legewie 1987).

In order to prevent the interpretation of the interviews suffering from a loss of information due to the translation of the Czech interviews into German, a Czech code/decode system was set up for the transcribed interviews conducted in Czech. In other words, the interpretation of single cases was carried out in the language of the corresponding interview.

\subsection{Results}

\subsubsection{Interest in cross-border cooperation}

The interpretation of the single interviews and the case-comparing interpretation permit the identification of the most important explanatory variables of the construct of psychic distance with regard to the entrepreneur's interest in crossborder cooperation. The main emphasis it put on the identification of the socalled core variables of this construct. Those variables prevent an individual from dealing more closely with a foreign country, i.e., factors in the perception of an entrepreneur that completely exclude or at least restrict the possibility of successful cross-border cooperation. The results of this examination clearly indicate that the conceptualizations usually employed in the literature have merely minor relevance to the measurement of this construct. Figure 4 illustrates the most important results which are explained in the following.

The differences between a foreign market and an individual's home market and their extent depends on the particular person's knowledge and experience. Despite the fact that the literature attaches particular importance to empirical knowledge (Johanson/Vahlne 1977), this analysis also recorded a great influence of objective knowledge on the interest in foreign commitment. Several interviewees admitted having a higher willingness to cooperate with neighbouring countries due to better objective knowledge (e.g., from the media). However, the findings of this analysis reflect Kornmeier's (2002) assumption that in this respect the objective state of knowledge is less important than the subjective belief in the state of knowledge. 
Figure 4. Summary of explanatory variables of the construct of psychic distance with regard to the interest in cross-border cooperation:

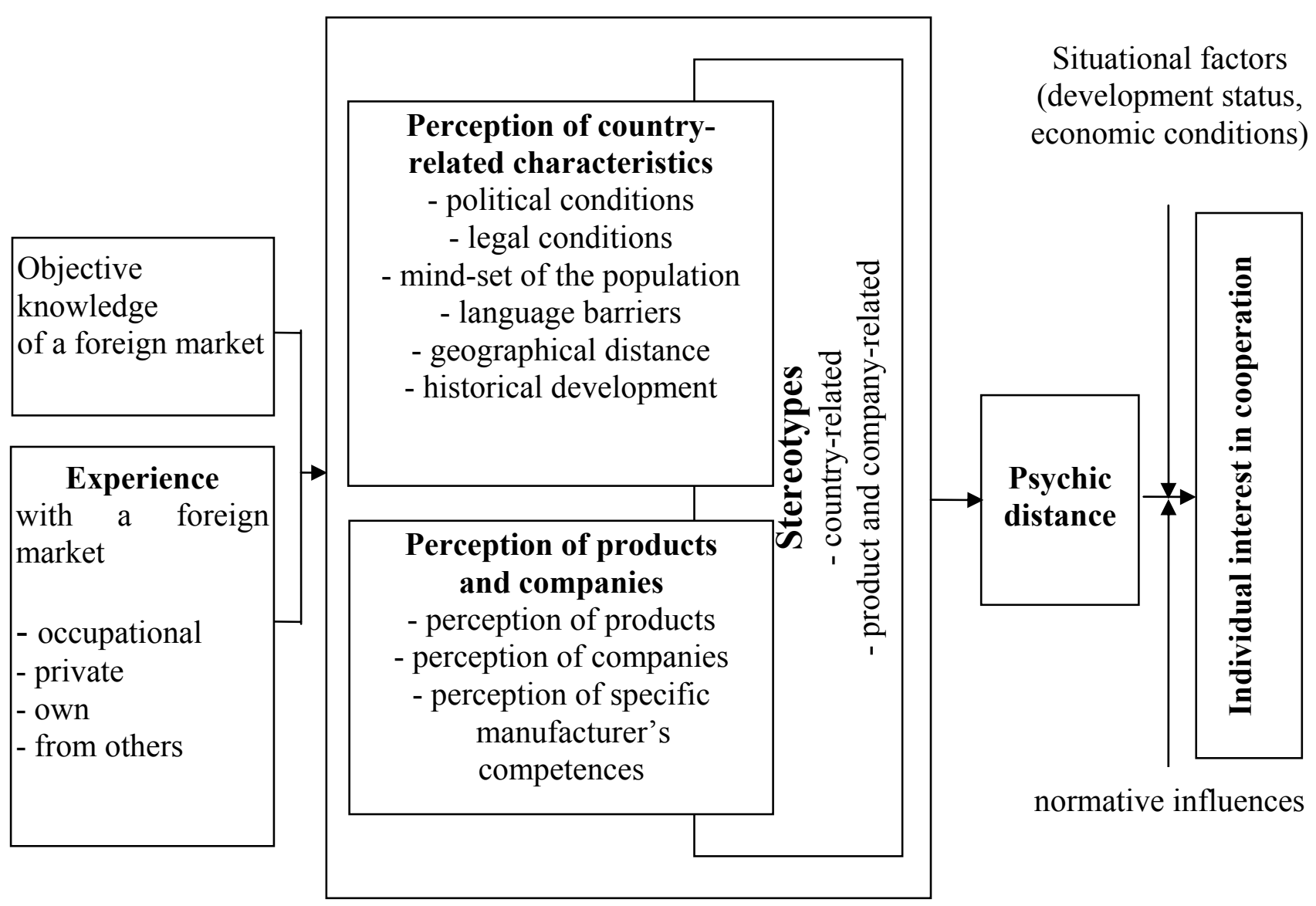

The division of experience into several types constitutes a central outcome of this analysis. Apart from occupational experience with a foreign market (workrelated stays abroad, previous cooperation), it is also private experience (e.g., vacation) that exerts influence on the perceived feeling of foreignness towards a country. Even one negative experience of a private or occupational nature can limit the individual's willingness to cooperate with a company from that country.

What is more, the evaluation of a foreign market is not only guided by personal experience. Other individuals' experience, of both an occupational and a private nature, is also included. This external experience does not necessarily have to originate from the individual's immediate environment such as friends or business partners. Experience of local companies in the country under examination is important as well.

So far, research on psychic distance has examined merely so-called countryrelated characteristics as possible explanatory variables for this construct. 
Starting out from findings of the country image research (Möller 1997), this analysis also includes so-called product- and company-related characteristics. The results indicate the great importance of these variables. Product- and company-related characteristics, such as quality, reliability, adherence to delivery dates are included when seeking a foreign cooperation partner, particularly if this search is for suppliers. The perception of product- and company-related characteristics, which is often based on national stereotypes, is closely linked to the perception of country-related characteristics, particularly the mind-set of the population and the country's stage of development.

Above all, the perception of so-called specific manufacturer's competences proved to be an important criterion for the evaluation of a potential commitment abroad. One reason for this lies in the possible transmission of country-of-origin effects (Gürhan-Canli/Maheswaren 2000; Scholzen/Schmidt 2003) to the (potential) customer. Both Saxon and Czech entrepreneurs considered for example Italian design or Japanese technology as good communication arguments.

The usage of country stereotypes for the evaluation of a foreign market also yields interesting findings which provide a basis for further research on psychic distance. Whereas the relevant literature attaches high importance to stereotypes particularly in the case of ignorance about an object (a country), the so-called orientation function of stereotypes (Hofstätter 1949), this analysis also indicates the frequent usage of national stereotypes when there is extensive knowledge and experience. This reveals on the one hand that national stereotypes have a real basis, which rests upon a country's historical and socio-political development. On the other hand stereotypes can also provide a certain confirmation.

So far, research on psychic distance itself has only sporadically included national stereotypes (Hallén/Wiedersheim-Paul 1984; Conway/Swift 2000). Kornmeier (2002) briefly scrutinizes this explanatory variable stating that there is a positive connection between prejudiced attitudes and psychic distance.

\subsubsection{Core variables of psychic distance in general}

The core variables of the construct of psychic distance comprise political stability and safety as well as legal conditions. Most entrepreneurs interviewed see these variables as exclusion criteria when they are looking for a foreign cooperation partner. Politically unstable and unsafe countries are consequently not taken into account at all in the process of considering cooperation abroad.

The relevant literature, however, strongly neglects political conditions as a possible indicator of the construct of psychic distance. Despite the fact that a large number of authors refer to the political situation as one of the possible reasons for the emergence of a feeling of foreignness, their relevance is only 
rarely surveyed empirically (Evans/Mavondo 2002; Dow/Karunaratna 2004; Evans/Bridson, 2005). Moreover, the majority of authors do not concentrate on perceived but on objective differences between two countries. However, the statements of the respondents show that the perception about which countries are politically safe or unsafe lacks interpersonal stability. Some entrepreneurs, for example, characterized Iraq or China as countries of risk whereas others perceive even European countries like Romania and Bulgaria, due to their political situation, as risky.

With regard to the perceived differences in economic conditions and development status, this analysis stands in fundamental contradiction to previous research findings on psychic distance. Despite the fact that economic conditions and development status are amongst the most frequently mentioned indicators of this construct (Evans/Mavondo 2002; Evans/Bridson 2005), this examination does not identify them as explanatory variables of psychic distance. This contradiction may be rooted in the choice of the dependent variables. While this analysis identifies possible explanatory variables of psychic distance with reference to the individual willingness for a commitment abroad (intended behaviour), the vast majority of previous works in this research area concentrates on the influence of psychic distance on the actual internationalization behaviour (e.g., on the export volume achieved).

As shown in figure 4, perceived differences in economic conditions and the development status are to be classified as situational variables. During the process of considering cross-border cooperation they are not related to the feeling of foreignness towards a country but only to the individual's interest in cooperation. This interest, for example, increases with prospects of higher profits, which may also exist in the case of a high perceived feeling of foreignness.

Apart from situational variables there are also normative influences, which represent factors that have no effect on the perceived feeling of foreignness towards a country, but only on the individual's interest in cooperation with that country. On the basis of Ajzen's Theory of Planned Behaviour, normative influences can be understood as 'subjective norms' (Ajzen, 1988). When considering cross-border cooperation, normative influences include, for example, supposed reactions of customers, which could be expected when cooperating with a particular country.

\subsubsection{Core variables of psychic distance for cooperation in the Saxon Czech border area}

Apart from examining the entrepreneur's interest in cross-border cooperation at the general level, the empirical study also analyzed a specific research area, namely the Saxon-Czech borderland. The inclusion of this specific examination perspective allows the identification of differences in the evaluation of 
individual explanatory variables of the construct of psychic distance in comparison with the general level.

The results of this study show that the core variables identified at the general level (political stability and safety as well as legal conditions) in the case of Saxon-Czech cooperation are merely of minor importance for all entrepreneurs interviewed. The political conditions of the neighbouring country are viewed as stable and safe and the interviewees do not associate the corresponding neighbouring country with political risks.

The core variables of psychic distance and consequently the exclusion criteria for the interest in cross-border cooperation in the Saxon-Czech border area, apart from the existing language barrier, mainly comprise the mind-set and the historical development.

Most of the respondents see large differences between the German/Saxon and the Czech mind-sets, which are considered to be a consequence of the distinctively determined cultural backgrounds of Germans and Czechs (Šroněk 2000). From the interviewees' point of view, these differences may affect the success of cooperation or even completely exclude entering into cooperation. Entrepreneurs with such experience particularly mention mind-set as an exclusion criterion for Saxon-Czech cooperation.

Moreover, the evaluation of the corresponding neighbouring country necessarily involves the perception of both countries' past relationship. This is reflected in the assessment of the people, but also of companies and of products there. Historical development as a possible explanatory variable of psychic distance has not been examined explicitly so far. This examination showed the great importance of historical development particularly for the evaluation of GermanCzech company relationships and to a lesser extent for the assessment of company relationships with other countries.

The analysis of the explanatory variables of the construct of psychic distance using the example of the Saxon-Czech border area made clear that the weighting of the variables identified at the general level is not universally valid. Bilateral relations between countries always include some specifics which have to be considered when investigating feelings of foreignness.

\section{Implications for practice}

Among the numerous works about the construct of psychic distance, only a surprisingly low number of studies deal with possible practical recommendations for the reduction of feelings of foreignness. The relevant literature particularly discusses starting points for the increase of cross-border business orientation for managers (Müller 1991), i.e. measures to increase the 
general willingness for commitment abroad. However, they do not explicitly refer to the perceived foreignness towards a particular country.

The development of action recommendations for entrepreneurs in small and medium-sized companies who show a high psychic distance and who are at the same time not willing to reduce it, is only possible within limits. It is therefore necessary to get recommendations from institutions outside companies like governments, local authorities, chambers of commerce or consultancies, which can stimulate the reduction of psychic distance 'from outside'. The findings of this study show that the feelings of foreignness originate from the perceived differences between the home and a foreign market. Therefore, it has to be the task of the external institutions to mediate appropriately, explain these differences and take measures to overcome them.

Examples of specific measures which contribute in the middle term to an increase in the individual's interest in cooperation amongst entrepreneurs are the organization of seminars and training, trade fairs and exhibitions, as well as cross-border company meetings and job markets.

The long-term reduction of psychic distance and consequently the long-term increase of the entrepreneurs' willingness to cooperate are certainly of fundamental importance. Amongst other things, this task is related to the reduction of existing prejudices. Since this requires a long period of time, it appears to be reasonable for local authorities to support a lively exchange of children and young people in particular. Bilingual pre-schools, student exchanges and common leisure time activities in townships near the border can add to the objective that younger generations perceive the coexistence of two nations in the border area as self-evident without drawing a dividing line between the 'own' and the 'strange'.

External institutions can increase both the objective knowledge about a foreign market (e.g., through seminars) and practical knowledge. Better knowledge of a specific foreign market may help identify additional differences between the home and a foreign market which would not exist where there is a low level of knowledge. These differences, however, become more specific in the entrepreneur's perception, and that allows him or her to overcome them more effectively.

Apart from external institutions, it is also the entrepreneurs themselves who can contribute to the reduction of psychic distance. Entrepreneurs whose enquiry for cross-border cooperation meets with distrust on the part of potential foreign cooperation partners are bound to change their perspectives. The entrepreneur has to face up to avoiding his ethnocentric point of view and to keeping the existing asymmetries at as low a level as possible. Specific measures could, for example, involve the participation in intercultural training or the usage of a 'neutral' language. 
Feelings of foreignness can furthermore be lowered by demonstrating a willingness to examine the home country of the potential cooperation partner more closely. Apart from the acquisition of objective knowledge about the country, one can emphasize the sincerity of intentions by being willing to learn the language of the potential cooperation partner. In particular, the latter point is of utmost relevance for the relationships in the Saxon-Czech border area. Table 2 gives an overview of the key recommendations for different actors.

Table 2. Key recommendations:

\begin{tabular}{|l|l|l|}
\hline Actor & Important goals & Exemplary measures \\
\hline Government & $\begin{array}{l}\text { - Improving preconditions for cross- } \\
\text { border activities } \\
\text { - Reduction of prejudices }\end{array}$ & $\begin{array}{l}\text { - Image campaigns } \\
\text { - Trade fairs and exhibitions } \\
\text { - Promoting cross-border acti- } \\
\text { vities (business, education, } \\
\text { private) }\end{array}$ \\
\hline Local authorities & $\begin{array}{l}\text { - Increasing knowledge about the neigh- } \\
\text { bouring country } \\
\text { - Promoting quality of living together in } \\
\text { border areas }\end{array}$ & $\begin{array}{l}\text { - Cross-border job training and } \\
\text { - Promoting youth exchange }\end{array}$ \\
\hline $\begin{array}{l}\text { Chambers of } \\
\text { commerce, } \\
\text { Consultancies }\end{array}$ & $\begin{array}{l}\text { - Increasing knowledge on opportunities } \\
\text { to cooperate } \\
\text { - Accompanying businesses during the } \\
\text { whole process of preparation for } \\
\text { cooperation }\end{array}$ & $\begin{array}{l}\text { - Organizing Seminars and } \\
\text { training } \\
\text { - Compendium on foreign market } \\
\text { entry } \\
\text { - Providing country experts }\end{array}$ \\
\hline Entrepreneurs & $\begin{array}{l}\text { - Avoiding ethnocentric point of view } \\
\text { - Acquisition of knowledge on the } \\
\text { neighbouring country }\end{array}$ & $\begin{array}{l}\text { - Participating in intercultural } \\
\text { training } \\
\text { - Using neutral language } \\
\text { - Studying language and culture }\end{array}$ \\
\hline
\end{tabular}

\section{Conclusion and implications for further research}

This paper provides important suggestions about the importance of psychic distance in the internationalization process for further research in the field of personality-related factors influencing an internationalization decision. The findings of the empirical study in the Saxon-Czech border area indicate that between entrepreneurs on both sides of the border there are feelings of foreignness towards the corresponding neighbouring country which limit the individual's willingness to cooperate with companies from the neighbouring country.

The theoretically-based conceptualization of the construct of psychic distance facilitates the identification of factors that are concealed behind the 'sum of factors' in Johanson/Vahlne's (1977) definition. Thus, this work contributes to the advancement of research on the effect of the entrepreneur's personal attitude on his or her internationalization decisions. However, it should be noted that there are some reservations with regard to the study carried out. Moreover, a 
number of research questions remain open which should be subject to further work.

A quantitative study should validate the explanatory variables of psychic distance identified in this study. This requires the development of a suitable instrument of measurement which takes into account both the perceived differences between countries and also their conceived consequences. This study was carried out in two countries. However, it would be desirable to include further countries from different cultures in order to evaluate the generalization of the findings.

The fact that this examination is a 'single-respondent study' - only one person per company was asked - is not regarded as a major problem since in all cases the focus was on companies where the interviewee was the central decision maker (owner or sole managing director). Thus, there would normally not have been a comparable second person in the company.

Demand for further research can also be seen with regard to the status of the construct of psychic distance amongst other entrepreneur- and company-related influence variables of an internationalization decision. Even though this paper suggested a concentration on psychic distance, further quantitative empirical studies are recommended to move on from the usual single-clue approach.

Moreover, how the conceived feelings of foreignness are reflected in the actual internationalization behaviour should be explored. Due to the explorative character of its formulated questions, this paper looked at intended behaviour. Further studies, however, should examine the internationalization behaviour which actually took place as a dependent variable. This could also help clarify which forms of cooperation are particularly prone to the influence of psychic distance. It is assumed here that the depth of the cooperation plays a role that the effects of psychic distance affect simple forms of cooperation like contract manufacturing much less than complex ones like cooperation in research \& development.

Last but not least, there is demand for research to determine the relevance of the construct of psychic distance in the time of globalization. There should be an analysis of whether subjective feelings of foreignness decrease due to the homogenization of markets. It would be particularly appropriate to perform longitudinal studies which could not only determine the effect of psychic distance on the internationalization behaviour, but also the importance of this construct during the single stages of the internationalization process. 


\section{References}

Ajzen, I. (1988): Attitudes, personality and behaviour. Chicago: The Dorsey Press.

Axinn, C.N./Matthyssens, P. (2001): Limits of internationalization theories in an unlimited world, in: International Marketing Review, 19, 5, 436-449.

Bamberg, S./Schmidt, P. (2000): Regulating transport: Behavioural changes in the field, in: Journal of Consumer Policy, 22, 479-509.

Beckerman, W. (1956): Distance and the pattern of intra-European trade, in: The Review of Economics and Statistics, 38, 1, 31-40.

Berndt, R./Altobelli, C.F./Sander, M. (2005): Internationales Marketingmanagement, 3rd ed., Berlin: Springer.

Binder, H./Lux, J. (2002): Bedeutung und Methoden einer bewußten Partnerwahl im Rahmen der Erfolgssicherung von Kooperationen, in: Macharzina, K./Oesterle, M.-J. (eds.): Handbuch Internationales Management, Wiesbaden: Gabler, 497-509.

Bleicher, K. (1992): Der Strategie-, Struktur- und Kulturfit Strategischer Allianzen als Erfolgsfaktor, in: Bronder, C./Pritzl, R. (eds.): Wegweiser für Strategische Allianzen: Meilen- und Stolpersteine bei Kooperationen, Wiesbaden: Gabler, 265-292.

Börsig, C./Baumgarten, C. (1997): Grundlagen des internationales Kooperationsmanagements, in: Macharzina, K./Oesterle, M.J. (eds.): Handbuch Internationales Management, Wiesbaden: Gabler, 475-496.

Bradley, F. (1991): International marketing strategy. Hemel Hempstead: Prentice Hall International.

Brezinski, H./Leick, B. (2004): Sächsisch-tschechische Wirtschaftskooperation: Unternehmensbefragung der TU Bergakademie Freiberg in Zusammenarbeit mit der IHK Südwestsachsen, TU Bergakademie Freiberg.

Bühner, R. (1991): Grenzüberschreitende Zusammenschlüsse deutscher Unternehmen, Stuttgart: Poeschel.

Castell, R. (2001): Tschechien, in Brenner, H./Dobisch, W.J. (eds.): Export-Guide Mittel- und Osteuropa: Erfolgreiche Geschäfte in Wachstumsmärkten, Köln: Dt. Wirtschaftsdienst, 447-478.

Child, J./Ng, S.H./Wong, C. (2002): Psychic distance and internationalization, in: International Studies of Management \& Organization, 32, 1, 36-56.

Conway, T./Swift, J.S. (2000): International relationship marketing: The importance of psychic distance, in: European Journal of Marketing, 34, 11/12, 1391-1414.

Cyert, R.M./March, J.G. (1963): A behavioral theory of the firm. Engelwood Cliffs: PrenticeHall.

Dichtl, E./Leibold, M./Beeskow, W./Köglmayr, H.-G./Müller, S./Potucek, V. (1983): Die Entscheidung kleinerer und mittlerer Unternehmen für die Aufnahme einer Exporttätigkeit, in: Zeitschrift für Betriebswirtschaft, 53, 5, 428-443.

Dichtl, E./Müller, S. (1992): Was erfolgreiche von erfolgslosen Exporteuren unterscheidet, in: Dichtl, E./Issing, O. (eds.): Exportnation Deutschland, , 2nd ed., München: Beck, 337357. 
Dow, D./Karunaratna, A. (2004): Developing a multidimensional instrument to measure psychic distance stimuli, Working Paper, University of Melbourne.

Endress, R. (1991): Strategie und Taktik der Kooperation: Grundlagen der zwischen- und innerbetrieblichen Zusammenarbeit, 2nd ed., Berlin: Erich Schmidt.

Evans, J./Bridson, K. (2005): Explaining retail offer adaptation through psychic distance, in: International Journal of Retail \& Distribution Management, 33, 1, 69-78.

Evans, J./Mavondo, F.T. (2002): Psychic distance and organizational performance: An empirical examination of international retailing operations, in: Journal of International Business Studies, 33, 3, 515-532.

Fletcher, R./Bohn, J. (1998): The impact of psychic distance on the internationalisation of the Australian firm, in: Journal of Global Marketing, 12, 2, 47-68.

Gürhan-Canli, Z./Maheswaran, D. (2000) Cultural variations in country of origin effects, in: Journal of Marketing Research, 37, August, 309-317.

Hallén, L./Wiedersheim-Paul, F. (1984): The evolution of psychic distance in international business relationships, in: Hagg, I./Wiedersheim-Paul, F. (eds.): Between market and hierarchy, University of Uppsala, 15-27.

Haussmann, H. (1997): Vor- und Nachteile der Kooperation gegenüber anderen Internationalisierungsformen, in: Macharzina, K./Oesterle, M.-J. (eds.): Handbuch Internationales Management, Wiesbaden: Gabler, 459-474.

Hiebsch, H. (1986): Interpersonelle Wahrnehmung und Urteilsbildung: Psychologische Grundlagen der Beurteilung, Berlin: Deutscher Verlag der Wissenschaften.

Hofstätter, P.R. (1949): Die Psychologie der öffentlichen Meinung. Wien: Braumüller.

Hofstede, G. (1993), Interkulturelle Zusammenarbeit: Kulturen - Organisationen Management. Wiesbaden: Gabler.

Holtbrügge, D. (2005): Die Lerntheorie der Internationalisierung von Johanson/Vahlne: Grundzüge, empirische Relevanz und Kritik, Working Paper No. 3, FriedrichAlexander-Universität Erlangen-Nürnberg.

Holzmüller, H.H./Kasper, H. (1990): The decision-maker and export activity: A crossnational comparison of the foreign orientation of Austrian managers, in: Management International Review, 30, 3, 217-230.

Johanson, J./Vahlne, J.E. (1977): The internationalization process of the firm: A model of knowledge development and increasing foreign market commitments, in: Journal of International Business Studies, 8, 1, 25-34.

Köhler, R./Hüttemann, H. (1989): Marktauswahl im internationalen Marketing, in: Macharzina, K./Welge, M.K. (eds.): Handwörterbuch Export und internationale Unternehmung, Stuttgart: Poeschel, 1428-1440.

Kornmeier, M. (2002): Kulturelle Offenheit gegenüber Auslandsmärkten: Auswirkungen psychischer Distanz im interkulturellen Marketing. Wiesbaden: Deutscher Universitäts-Verlag.

Lamb, P.W./Liesch, P.W. (2002): The internationalization process of the smaller firm: Reframing the relationships between market commitment, knowledge and involvement, in: Management International Review, 42, 1, 7-26. 
Larimo, J. (2003): Internationalisation of smes: Two case studies of Finnish born global firms, in: Blomsterno, A./Sharma, D.D. (eds.): Learning in the internationalisation process of firms, Cheltenham: Edward Elgar, 258-280.

Legewie, H. (1987): Interpretation und Validierung biographischer Interviews, in: Jüttemann, G./Thomae, H. (eds.): Biographie und Psychologie, Berlin: Springer-Verlag, 138-150.

March, J.G./Simon, H.A. (1976): Organizations. Cambridge: Blackwell.

Mayring, P. (2002): Einführung in die qualitative Sozialforschung: Eine Anleitung zu qualitativem Denken, 5th ed., Weinheim: Beltz.

Mayring, P. (1997): Qualitative Inhaltsanalyse: Grundlagen und Techniken, 6th ed., Weinheim: Deutscher Studien-Verlag.

McGaughey, S./Welch, D./Welch, L. (1997): Managerial influences and sme internationalisation, in: Björkman, I./Forsgren, M. (eds.): The Nature of the International Firm: Nordic Contributions to International Business Research, Copenhagen: Business School Press, 165-188.

Möller, T. (1997): Landesimage und Kaufentscheidung: Erklärung, Messung, Marketingimplikationen. Wiesbaden: Deutscher Universitäts-Verlag.

Müller, S. (1991); Die Psyche des Managers als Determinante des Exporterfolges: Eine kulturvergleichende Studie zur Auslandsorientierung von Managern aus sechs Ländern, Stuttgart: M\&P Verlag.

Müller, S./Köglmayr, H.G. (1986): Die psychische Distanz zu Auslandsmärkten: Ein verkanntes Exporthemmnis, in: Schmalenbachs Zeitschrift für betriebswirtschaftliche Forschung, 38, 9, 788-804.

Müller, S./Kornmeier, M. (2002): Strategisches Internationales Management. München: Vahlen.

Müschen, J. (1998): Markterschließungsstrategien in Mittel- und Osteuropa. Bergtheim: Deutscher Wissenschafts-Verlag.

Nordström, K.A./Vahlne, J.E. (1994): Is the globe shrinking? Psychic distance and the establishment of Swedish sales subsidiaries during the last 100 years, in: Landeck, M. (ed.): International trade: Regional and global issues, New York: Palgrave Macmillan, 41-56.

Pfohl, H.Chr./Braun, G.E. (1981): Entscheidungstheorie: Normative und deskriptive Grundlagen des Entscheidens. Landsberg am Lech: Verlag Moderne Industrie.

Roll, O. (2003): Internetnutzung aus Konsumentensicht: Eine qualitativ-empirische Untersuchung auf handlungstheoretischer Basis. Wiesbaden: Deutscher UniversitätsVerlag.

Schäper, C. (1997): Entstehung und Erfolg zwischenbetrieblicher Kooperation: Möglichkeiten öffentlicher Förderung. Wiesbaden: Deutscher Universitäts-Verlag.

Scholzen, J.N./Schmidt, R. (2003): Der Einfluss der Produktvertrautheit auf den Country-ofOrigin-Effekt, in: Die Unternehmung, 2, 101-113.

Schroll-Machl, S., (2000): Handlungswirksamkeit zentraler Kulturstandards in der Interaktion zwischen Österreichern, Deutschen und Tschechen, in: Fink, G./Feichtinger, C. (eds.), Kulturstandards und interkulturelle Kommunikation anhand empirischer Ländervergleiche, Wien: Böhlau, 88-122. 
Simon, H.A. (1997): Models of bounded rationality, Vol. 3, Empirically grounded economic reason. Cambridge: The MIT Press.

Sousa, C.P./Bradley, F. (2005): Global markets: does psychic distance matter?, in: Journal of Strategic Marketing, 13, 1, 43-59.

Sousa, C.P./Bradley, F. (2006): Cultural distance and psychic distance: Two peas in a pod?, in: Journal of International Marketing, 14, 1, 49-70.

Šroněk, I. (2002), Kultura vmezinárodním podnikání. Praha: Grada.

Stöttinger, B./Schlegelmilch, B.B. (1998): Explaining export development through psychic distance: Enlightening or elusive?, in: International Marketing Review, 15, 5, 357372 .

Stöttinger, B./Schlegelmich, B.B. (2000): Psychic distance: a concept past its due date?, in: International Marketing Review, 17, 2, 169-173.

Thomas, A. (1991): Psychologische Wirksamkeit von Kulturstandards im interkulturellen Handeln, in: Thomas, A. (ed.): Kulturstandards in der internationalen Begegnung, Saarbrücken: Breitenbach, 55-69.

Wiedersheim-Paul, F./Olson, H.C./Welch, L.S. (1978): Pre-export activity: The first step in internationalization, in: Journal of International Business Studies, 9, 1, 47-58.

Zhu, L./Yang, J. (2004): The role of psychic distance in contagion: A gravity model for contagious financial crises, Working paper, The George Washington University.

Zich, F. (1999): Nositelé přeshraniční spolupráce na česko-německé hranici, Working Paper, Praha: Sociologický ústav AV ČR. 